\title{
T NTERMARIUM: THE BALTIC AND THE BLACK SEAS ON THE POLISH MENTAL MAPS IN THE INTERWAR PERIOD
}

\section{Marta Grzechnik}

University of Greifswald, E-Mail: marta.grzechnik@eui.eu

\section{Acknowledgments}

This paper has been presented at the Fourth International Conference on Nordic and Baltic Studies „Empire-building and Region-building in the Baltic, North and Black Sea Areas", in Constanta, Romania, May 24-26, 2013. Supported by a grant from Iceland, Liechtenstein and Norway (Finantat prin fonduri donate de Islanda, Liechtenstein si Norvegia)

\begin{abstract}
:
The aim of the paper is to examine and compare how the Baltic Sea on the one hand and the Black and Aegean Seas on the other were conceptualized in the Polish scholarly and political discourse in the interwar period, and how mental maps of Poland's connection to both sea regions were constructed. Because of the direct access to Baltic Sea, the link to it was more straightforward, although it was constantly questioned by German revisionist scholarship. In the south there was no territorial connection to the seas - it was to be established on the political and economic level, for example through so-called Intermarium idea. An interesting question is also to what extent the discourses connected with the Baltic and the southern European seas fell within the same discourse of the ideology of the sea, and to what extent they were contradictory or mutually exclusive.
\end{abstract}

\section{Rezumat:}

Scopul acestei lucrări este acela de a analiza și compara modul in care au fost conceptualizate $\hat{\imath}$ discursul științific și politic polonez din perioada interbelică Marea Baltică, pe de o parte, și Marea Neagră și Marea Egee, pe de altă parte, și cum au fost construite hărțile mentale ale legăturilor Poloniei cu cele două regiuni maritime. Datorita accesului direct la Marea Baltică, legătura a fost mai simplă, deși a fost pusă în mod constant sub semnul întrebării de către scrierile revizioniste germane. In partea de sud nu a existat nici o legătură teritorială cu aceste mări - a trebuit să fie stabilită la nivel politic și economic, de exemplu, prin așa-numita idee 
Intermarium. O întrebare interesantă este, de asemenea, în ce măsură discursurile legate de Marea Baltică și mările din sudul Europei s-au integrat aceluiași discurs al ideologiei mării și în ce măsură au fost contradictorii sau s-au exclus reciproc.

Keywords: Poland; interwar; Baltic Sea region; Black Sea region; Intermarium; mental maps; Baltic Institute

\section{Introduction}

The idea of "Intermarium", formulated in interwar Poland as a principle of foreign policy, rested on the notion of Poland as an intermediary between the Baltic Sea on the one hand and the Black and Aegean Seas on the other. While historical claims to the Baltic Sea connection seem more obvious, the link to the southern European seas was also not without historical background, as the catchphrase Polska od morza do morza ("Poland from one sea to the other") exemplifies. The aim of this paper is to examine and compare how these seas were conceptualized in the Polish discourse in the interwar period, and how mental maps of Poland's connection to both sea regions were constructed.

\section{Poland in the interwar period}

Point 13 of the American President Woodrow Wilson's list of postulates for the shape of Europe after the end of the First World War was about the creation of independent Poland with access to the sea, corresponding to the idea of self-governance of nations which guided the whole project. This was indeed made reality by the decisions of the Versailles Peace Conference ending the war. Poland became an independent and maritime country in the sense of having access to the sea through a narrow stretch of Pomerania along the Vistula river, lying between Germany and East Prussia. This settlement raised mixed feelings in Poland, as the sea coast was considered too difficult to defend and too short for pursuit of active maritime policy: it was only about 74 kilometers long (not including the $\mathrm{Hel}$ peninsula). It also did not include any major port, as Danzig was left outside of Polish borders and made a Free City under the League of Nations instead, in customs union with Poland. Poland had the right to use the port in Danzig, however in practice cooperation with the German-dominated city turned out to be far from smooth. 
Poland gained de facto access to the sea in February 1920, when the Polish Army entered Pomerania. On 10 February in Puck (a small port town north of Danzig) a ceremony of the so-called "Poland's Wedding to the Sea" was performed. It was most probably inspired by an analogous Venetian tradition and consisted in General Józef Haller riding into the sea on horseback and casting a platinum ring into it. A special session of the Polish parliament was also held on the same day. The fact of Poland gaining access to the sea was thus emphasized by grand gestures - "invented traditions" in Hobsbawm's and Ranger's understanding. ${ }^{1}$ Even the limited access to the sea inspired the country's elites to develop a certain attitude to the sea, an ideology connected to it. One practical application of this attitude was the decision to construct a port, not far from the borders with the Free City of Danzig, in the fishermen village of Gdynia. The Minister of Industry and Trade, Eugeniusz Kwiatkowski, ${ }^{2}$ was among the active proponents of the building of the port, but in many ways it was seen as a great task undertook by the whole nation, a source of national pride. The construction proceeded quickly, especially after 1926 and by 1938, when trans-shipments via Gdynia reached 9 million tons, it was already the biggest port on the Baltic Sea and tenth-largest in Europe. ${ }^{3}$

All these facts could suggest that after regaining independence and the sea coast Poland would enter active Baltic Sea region cooperation - this, however, turned out not to be so straightforward. Throughout the interwar period the country had strained relations with almost all of its neighbors, including those on the Baltic Sea. The dispute over Vilnius with Lithuania, for example, was one of the major reasons for the failure of the planned cooperation of the Baltic Sea countries, the Baltic League. ${ }^{4}$ Relations with Germany were even worse, especially with regards to the Baltic Sea coast, as the Germans resented the decision of Versailles of separating the territory of East Prussia from the rest of their country by the so-called Polish or Danzig Corridor.

\footnotetext{
${ }^{1}$ Eric Hobsbawm, 'Introduction: Inventing Traditions,' in The Invention of Tradition, ed. E. Hobsbawm, T. Ranger (Cambridge: Cambridge University Press, 1983), 1-14.

2 In office 1926-30; later, in 1935-39, Minister of Treasure and Deputy Prime Minister.

3 Bogusław Dopierała, Wokót polityki morskiej Drugiej Rzeczypospolitej. Studia historyczne (Poznań: Wydawnictwo Poznańskie, 1978), 359.

${ }^{4}$ Marko Lehti, A Baltic League as a Construct of the New Europe (Frankfurt am Main, New York: Peter Lang, 1999), 254-5.
} 
The situation in the south was not much better; at least there, however, was Romania, almost the only neighbor - except for Latvia - with whom relations remained good. Poland did not have access to the Black Sea, although, which is perhaps worth reminding, its territorial shape in the interwar period placed it much closer geographically to this sea than its present day counterpart, as it stretched further to the south and especially to the east. In this international situation regional cooperation, making the full economic and military use of the sea, as well as using sea routes for transit, even through the territory of another country, was difficult.

\section{Maritime Poland?}

The origins of interwar Poland's attitude to the sea lie in the nineteenth century, when many intellectuals discussed the reasons for the fall of the state and visions of its shape in the future, after regaining independence. Access to the sea - though earlier most often neglected - was appreciated, and the shape of the reborn state was designed as stretching, as in the past, od morza do morza - "from one sea to the other": a reference to the Polish-Lithuanian Commonwealth's times of greatness, when the country's territory reached from the shores of the Baltic Sea in the north to the Black Sea in the south-east. As Stefan Troebst argues, it was around the turn of the nineteenth and the twentieth centuries that on the Polish mental maps the image of the sea changed from negative to positive..$^{5}$ Earlier these maps, in their maritime aspects, were dominated by the nobles' fear of the sea and scorn of the tradesmen of Danzig who drew their riches from it.

This new found enthusiasm for the sea remained current in the interwar period, despite the disappointment with the short coast given to Poland at Versailles. In order to popularize maritime issues in the society, an organization called Stowarzyszenie Pracowników na Polu Rozwoju Żeglugi Bandera Polska (The Association of Workers for Development of Navigation "Polish Flag") was founded in 1918; it underwent several name changes in the subsequent years, finally settling for Liga Morska i Kolonialna (Maritime and Colonial League) in 1930. The League propagated maritime education, supported the building of the navy and merchant marine, and later also

\footnotetext{
5 Stefan Troebst, '"Intermarium" and "Wedding to the Sea": Politics of History and Mental Mapping in East Central Europe', European Review of History 10 (2003), 313. 
started propaganda of colonial expansion in Liberia and Madagascar. ${ }^{6}$ It was also by its initiative that, for example, the "Holidays of the Sea" were organized since 1932 until the outbreak of the war. Furthermore, in 1918 a Naval Section (later transformed into a Maritime Department) was created in the Ministry of War with Rear-Admiral Kazimierz Porębski at its head and creating a merchant marine and naval fleet as its aim.

On the other hand, it is debatable whether there existed at all a clear and consistent maritime policy. ${ }^{7}$ Despite the dynamic development of the Baltic Sea port in Gdynia, the Polish merchant fleet remained comparatively small throughout the interwar period. They were thus not politicians, but intellectuals, mainly scholars, who strove to put the sea on the Polish nation's mental maps by creating an outline of a maritime program. This program included first of all propaganda of the sea in the society, bringing out maritime elements in the Polish history, promoting the awareness of the sea's importance for economy and security, as well as the fundamental importance of popular maritime consciousness for united, strong and independent Poland..$^{8}$ Of course, because of the direct access to the Baltic, it was this sea that was the subject of most actions promoting such consciousness, even though this access was narrow and throughout the whole interwar period challenged by Germany. But perhaps exactly this made this promotion all the more fervent. It did not only take the form of invented traditions such as the ones mentioned above (the Wedding to the Sea, the Holidays of the Sea etc.), but became also the subject of extensive research. The institution responsible for most of this research was the Baltic Institute, established in 1925 in Torun. Apart from following the maritime program by striving to form in the Polish society and its leaders maritime consciousness which would translate into an active maritime policy of the state, the Institute's research also aimed to put forward arguments for Poland's right to direct access to the Baltic Sea. Most often they were at the same time counterarguments to German research, which argued, among others, that Poles were not a maritime nation and therefore did not need access to the sea nor its own ports. Finally, and to a lesser extent, the Institute

\footnotetext{
6 Arkadiusz Kołodziejczyk, 'Liga Morska i Kolonialna,' in Encyklopedia Historii Drugiej Rzeczypospolitej (Warszawa: Wiedza Powszechna, 1999), 191.

7 See e.g.: Dopierała, 267-73.

8 Bernard Piotrowski, W stużbie nauki i narodu. Instytut Battycki w latach 1925-1939 (Poznań: Wydawnictwo Naukowe UAM, 1991), 16-25.
} 
promoted interest in the other Baltic Sea region countries and building of a Baltic Sea region community.

There was a reason why so much emphasis was put on shaping the Polish maritime awareness: its current state was rather poor. Such was the opinion for example of Stanisław Srokowski, the Institute's first director, expressed in a brochure Instytut Battycki i jego zadania (The Baltic Institute and its tasks) published shortly after the founding of the institution. The sea did not form part of the Polish national landscape in the way that for example the Tatra mountains and the city of Vilnius did, he argued, and for some even Pomerania - the territory of the Polish Baltic Sea littoral - was not an essential part of the state and thus was not worth defending in case of a possible future war. "The Polish sea shore in our everyday concepts" Srokowski wrote, "is still some distant borderland, not the country's lungs and indispensable organ of its free existence." ${ }^{9}$ The fact that this way of thinking was shared by the Polish authorities meant that there was a serious risk of wasting the sea's potential.

What was the Institute's remedy for this situation? First and foremost popularizing the knowledge about the sea and its significance for Poland, which was done through publications of various types - e.g. the series of monographs called 'Pamiętnik Instytutu Bałtyckiego' ('Records of the Baltic Institute'), pamphlets in foreign languages published since 1933 ('Biblioteczka Bałtycka' - 'Baltic Pocket Library') and 'Komunikaty' ('Bulletins'), which were short brochures (1-2 pages), usually containing one article analyzing a problem or an aspect of the Institute's activity, and were sent out free of charge to different research and trade institutions, editors and press agencies. The Institute also published two journals: a quarterly Jantar (Amber) and, since 1935, an English language Baltic Countries: a survey of the peoples and states on the Baltic with special regard to their history, geography and economics (in 1937 it changed name to Baltic and Scandinavian Countries...). Furthermore, the Institute organized lectures. For example in the years 19311933 a series of them took place in Gdynia and their texts were later published in the form of the book Światopoglad morski (Maritime outlook). They tackled such issues as economy, geography and history, all connected by the topic of the sea and its role in the shaping of culture and economy, as Józef

\footnotetext{
${ }_{9}$ Stanisław Srokowski, Instytut Bałtycki i jego zadania (1926), 3. 
Borowik, the editor of the volume and the Institute's long time director emphasized. ${ }^{10}$

A characteristic for the Baltic Institute's research set of arguments is presented in the first essay in the book, Franciszek Bujak's 'Kultury morskie i lacdowe' ('Sea and land cultures'). It is an analysis of world civilizations, past and present, which divides them into two types: sea and land cultures. According to Bujak they are the former that develop positive qualities such as willpower, enterprise, open-mindedness, hunger for knowledge and, in the long perspective, patriotism. ${ }^{11} \mathrm{He}$ also argues that access to the sea and maritime trade are crucial for a country's development in the modern world, and "without seafaring every society is a cultural cripple and like a cripple it has worse perspectives in competition with other societies: its inescapable fate is dependence and poverty."12 It was this crippling that had caused Poland's fall in the past and only a strong presence on the Baltic Sea coast could guarantee that this would not repeat in the future.

The promotion of the vision of the Baltic Sea as something indispensable for Poland's development was also done through presenting economic arguments and underlining the importance of the sea as a trading route. This was paired with appealing frequently in publications and on conferences $^{13}$ to the Polish authorities for an active maritime policy and developing seaports, especially Gdynia. Kwiatkowski, the above mentioned Minister of Industry and Trade and supporter of the building of Gdynia, was among the authors whose texts about the economic importance of sea trade and ports were published by the Institute. ${ }^{14}$

The point of reference of these and others actions aiming to promote the maritime outlook was the Baltic Sea, as the one to which Poland had direct access (although the Maritime and Colonial League had more global ambitions, as indicated by their plans of colonial expansion $\left.{ }^{15}\right)$. The challenge

\footnotetext{
10 Józef Borowik, 'Przedmowa,' in Światopogląd morski, ed. idem (Toruń: Wydawnictwa Instytutu Bałtyckiego, 1934), xv.

11 Franciszek Bujak, 'Kultury morskie i lądowe,' in ibidem, 5.

12 Ibid., 18.

${ }^{13}$ For example a conference in 1936 devoted entirely to the development of Gdynia.

14 E.g.: Eugeniusz Kwiatkowski, 'Powrót Polski nad Bałtyk,' in Obrona Pomorza, ed. J. Borowik (Torun: Wydawnictwa Instytutu Bałtyckiego, 1930), 1-20.

15 The idea of colonial expansion followed from conviction that Poland, after regaining independence, should join the great states of Europe in the race for colonies in other parts of the world - for example by taking over some of the former German colonies currently under the administration of the League of Nations. The logic behind these projects was on the one
} 
here was - apart from the perceived lack of identification with the sea and maritime issues - the revisionist statements of German scholarship and politics arguing that Poland did not need access to the sea and that the "corridor" was an unnatural creation disrupting the life of Germany and especially its part cut off by it - East Prussia.

When it comes to the southern European seas, the challenge was, of course, geographical distance and lack of territorial connection. Such connection was to be established on political and economic level, through the idea of Międzymorze - Intermarium. It was an idea of Polish foreign policy formulated in the circles around Józef Piłsudski, and used especially by the later Minister of Foreign Affairs Józef Beck (in office 1932-39). It envisaged Poland as a regional power and leader to the countries situated between the two threatening countries: the USSR and Germany, and at the same time in the belt between the Baltic and the Black Seas - hence Intermarium, a clear reference not only to both seas, but first of all to the already mentioned vision of Poland stretching "from one sea to the other", as in its great past. Apart from the political dimension of a strategic alliance under Polish leadership, this Intermarium was to be established on an economic level through transport connections, which would at the same time help to diversify transit routes in face of the vulnerable strategic position of Poland on the Baltic Sea coast, difficult to defend in case of war. This direction of developing trading links seemed all the more suitable taking into consideration that Romania, through which those routes were supposed to run, was almost the only neighbor with which Poland maintained good relations in the interwar period. Two projects were put forward: one involved building channels joining the Baltic with the Black Sea via rivers Vistula, San, Dniester, Prut

hand that of prestige and ambition to join the European powers on an equal footing, an on the other - of securing raw materials and counteracting overpopulation in the country. Although some attempts were undertaken in Liberia, where the Maritime and Colonial League set up coffee plantations, the project turned out to be a failure - in part due to the hostility of the traditional colonial powers, but first of all the fact that the whole project was more a result of an overblown sense of Polish strength than of careful planning and rational assessment of the international situation. Piotr Łossowski, Polska w Europie i na świecie 19181939. Szkice z dziejów polityki zagranicznej i położenia międzynarodowego II Rzeczypospolitej. (Warszawa: Książka i Wiedza, 1990), 110-20. At the same time, despite the dynamic development of the Baltic Sea port in Gdynia, the Polish merchant fleet, even still in the second half of the 1930s, was comparatively small - smaller even than those of the Baltic States Estonia and Latvia, according to Józef Borowik's estimate in 1937. With these resources it was hard to think about developing deep-sea trade on the world's oceans, let alone becoming a colonial power. Piotrowski, 202. 
and Danube; another - a railway connection to the Aegean Sea via Romania, Bulgaria or Yugoslavia and Greece. These trade connections were supposed to make the countries involved more independent of the threatening regional powers: the arguments were both economic and strategic. However, neither of the projects was realized, as both financial reasons and political disputes between the involved countries turned out to be too big a hindrance. ${ }^{16}$

Figure 1: The proposed route joining the Baltic and the Black Seas via rivers and channels

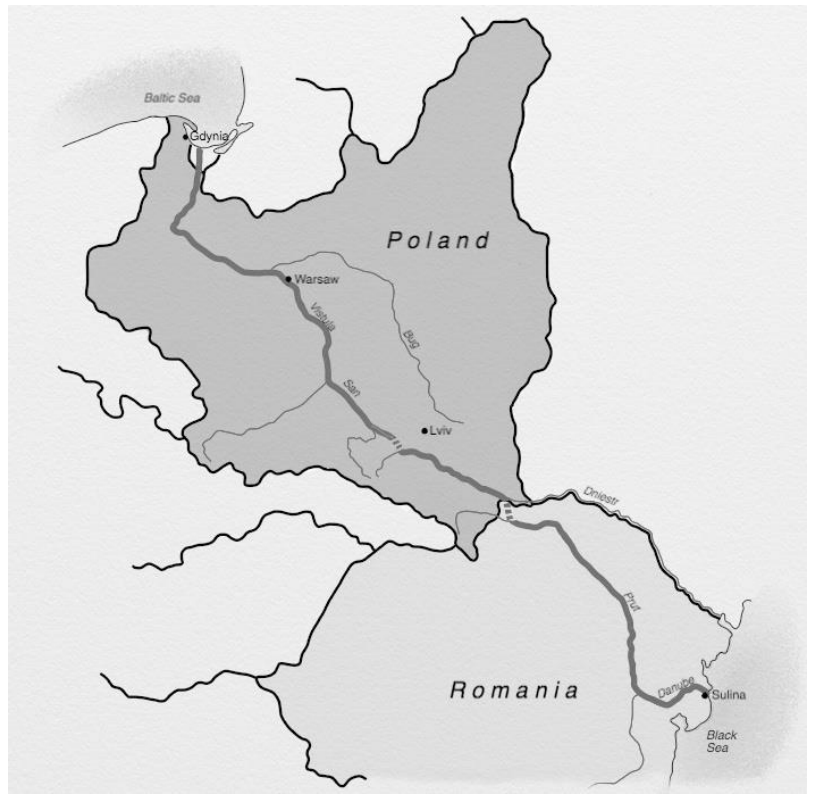

\section{North and south}

It is an interesting issue how much the discourses connected with the Baltic and the southern European seas - mainly the Black Sea - fell within the same discourse of the ideology of the sea, and to what extent they were in fact contradictory or even mutually exclusive. Did the two seas form parts of the same mental map? Could interwar Poland with all justification be indeed called a country between the seas, a bridge connecting them - an Intermarium?

\footnotetext{
16 Elżbieta Znamierowska-Rakk, 'Sprawa połączenia Bałtyku z Morzem Czarnym i Morzem Egejskim w polityce II Rzeczypospolitej,' in Międzymorze. Polska i kraje Europy ŚrodkowoWschodniej XIX-XX wiek. Studia ofiarowane Piotrowi Łossowskiemu w siedemdziesiata rocznice urodzin, ed. A. Ajnenkiel et al. (Warszawa: Instytut Historii PAN, 1995), 287-98.
} 
Both among the ideologists of the Polish maritimity and economists discussing potential of the country's geographical location were ones embracing such a vision of Poland. For example the editors of the English language journal of the Baltic Institute, Baltic and Scandinavian Countries, declared that countries "not belonging to the [Baltic] region, but connected with it by the ties of a common history or culture, or by racial affinity, are dealt with on occasion. Important among these are the lands lying between the Baltic and the Black Sea."17 Some - although not numerous - articles on these topics did indeed appear in the journal, for example 'The Baltic and the Black Sea in Medieval trade' by Marian Małowist ${ }^{18}$ and 'The Dardanelles and the Sound' by Bolesław Leitgeber ${ }^{19}$ (both in 1937).

Towards the end of the interwar period, and especially in the second half of the 1930s, economists, including those cooperating with the Baltic Institute and therefore clearly interested in maritime matters, saw the economic advantage of a connection - by way of rivers and canals - to the Black Sea.20 The Baltic Sea ports of Gdynia and Danzig could in this way become connected to the East Central European hinterland and the Baltic Sea trade could gain trade links to the south. Apart from increasing Poland's own economic potential and the ports' competitiveness in comparison to Stettin and Hamburg, these projects were seen as answers to the ones prepared in Germany, where canals connecting Baltic Sea ports (e.g. Stettin) to Danube and by it to the Black Sea were also planned, and as a way of diminishing the German sphere of influence in the countries to the south (Austria, Czech Republic). ${ }^{21}$ With the development of economy and infrastructure on the one hand and an increasingly threatening situation on the international arena on the other, the ideas of economic expansion in multiple directions were put forward - goods as well as military shipments were to be transferred via Baltic and Black Sea ports, making international

\footnotetext{
17 'Editorial Policy', Baltic and Scandinavian Countries. A survey of peoples and states on the Baltic with special regard to their history, geography and economics 4 (1938).

18 Marian Małowist, 'The Baltic and the Black Sea in Medieval trade,' Baltic and Scandinavian Countries. A survey of peoples and states on the Baltic with special regard to their history, geography and economics 3 (1937): 36-42.

19 Bolesław Leitgeber, 'The Dardanelles and the Sound,' Baltic and Scandinavian Countries. A survey of peoples and states on the Baltic with special regard to their history, geography and economics 3 (1937), 71-6.

20 Piotrowski, 228.

${ }^{21}$ Ibid.

90
} 
transport more independent of the hostile neighbors (mainly Germany).22 For this, of course, further development of merchant marine and the navy was necessary. Coupled with the project of alliance with the countries of the Intermarium this constituted, in the words of the historian Bogdan Dopierała, Minister Beck's "Jagiellonian dreams of greatness". 23

This reference to the historical Polish-Lithuanian dynasty of Jagiellons (ruling in the fourteenth to sixteenth centuries) reminds of the origins of the Intermarium idea as a reference to the past greatness of the Polish-Lithuanian Commonwealth: it was during the rule of these kings that the country's expansion reached the shores of the Black Sea, making it stretch from one sea to the other. At the same time it also refers to the two competing strands of thought about Poland's vision of itself and its place in East Central Europe which appeared in the country at the beginning of the twentieth century, and which were named after two historical ruling dynasties. It was the Jagiellon vision that looked to the south and the east, and saw Poland as multiethnic, imperial and federalistic. In the current situation the control of the south-eastern territories all the way to the Black Sea (as in the times of the Jagiellons) was to be replaced by cooperation between Poland and the small countries occupying these territories - cooperation in which Poland was to be the regional leader.

The other vision was named after the Piasts, the dynasty ruling in Poland before 1370, whose representatives were supposed to be the ones with a good understanding of the importance of access to the sea and control over the estuaries of rivers Vistula and Oder. This ideology was thus oriented towards the west and the north, seeing Poland in opposition to the Germans and concentrated on what was defined as "ethnically Polish territories" - a concept comprising roughly Greater and Lesser Poland, Masovia and Pomerania, including the estuaries of both rivers. ${ }^{24}$ While the former vision was attributed to the group around Józef Piłsudski and his

\footnotetext{
22 Although the projects involving the construction of channels and railway bridges were unsuccessful, some transport connections were established. For example the Romanian port in Constanța was used for import of military equipment from France before the outbreak of the Second World War. There appeared also arguments that the basins of Dniester, Prut and Seret were as natural hinterland of Gdynia and Danzig as Vistula. Cf.: Leszek Kirkien, Między Wista a ujściem Dunaju. Problem bałtycko-czarnomorski (Warszawa: Instytut Wschodni, 1932).

${ }^{23}$ Dopierała, 322-3.

24 See e.g.: Zygmunt Wojciechowski, ‘Rozwój terytorialny Prus w stosunku do ziem macierzystych Polski,' in Światopoglad morski, 99.
} 
followers (as Minister Beck), the Piast idea connected to the national democratic thought of Roman Dmowski, who was a representative for Poland at the Versailles Peace Conference, fighting for recognition of its right to independence and access to the sea. His vision focused on "ethnically Polish territories" and referred to the Middle Ages and the Piasts' fights with their German enemies.

The Piast and Jagiellon visions were often set against each other as two alternatives of Poland's foreign policy and its attitude towards neighbors. The Baltic Institute, the main advocate of the active maritime policy, was among those who usually saw it that way - and furthermore its scholars often pointed to the Piast tradition as the one Poland should choose. For example Wacław Sobieski, a historian sympathizing with Dmowski's National Democrat movement and collaborator of the Baltic Institute, in his book arguing for Polish right to access to the sea and active maritime policy, referred to the Piast kings and princes - especially Bolesław Krzywousty (Boleslaus the Wrymouth, ruling 1107-38) - as examples worth following in their consistent efforts to secure control over the Baltic Sea coast and the estuaries of Vistula and Oder. The Jagiellons had not exhibited similar consistency or understanding of the active northern policy, they abandoned this direction in order to concentrate on expansion to the south and the east - and therefore were criticized. ${ }^{25}$

This is not to say that the Baltic Institute was connected to Dmowski and his political movement, or even that the Polish discourse related to the Baltic Sea was of interest only to those who identified themselves with this movement: it was a topic in which intellectuals of different political views were interested (and different academic centers as well, even as far away from the Baltic Sea as Cracow or Lviv). ${ }^{26}$ It has already been mentioned that one of the authors who presented their views in the Institute's publications was Minister Kwiatkowski, who, in the 1930 volume Obrona Pomorza (The Defence of Pomerania) criticized the historical rulers of Poland for neglecting the matters of the sea and concentrating too much on other directions of foreign policy, whereas only the strong stance in the west and on the Baltic Sea shore could give the country enough strength to secure the eastern

\footnotetext{
25 Wacław Sobieski, Walka o Pomorze (Poznań: Nakład Księgarni św. Wojciecha, 1928).

26 Jörg Hackmann, 'Zugang zum Meer: Die Ostsee in der polnischen Historiografie,' Nordeuropaforum 2 (2004): 43-66, accessed at http://edoc.huberlin.de/nordeuropaforum/2004-2/hackmann--joerg-43/XML/ on 5.04.2013. 
borderlands. ${ }^{27}$ This reflected the Institute's conviction that throughout Polish history neglecting Baltic Sea matters came hand in hand with crises in the country's development and the postulate that the society's attention should be fixed on the sea and the north (which was essential to Poland's security and welfare), and turned away from the east (where it had been fixed for centuries, from which only crises and dissolution of the state in the eighteenth century had come). This was the only way for Poland "not to lose itself, and [for] our Polish work not to disperse on the vastness and wilderness of the Eastern lands" - as Franciszek Bujak wrote in his essay comparing sea and land cultures in the Światopoglad morski volume. ${ }^{28}$

Moreover, seen from the perspective of this sea - land opposition proposed by Bujak, the south-eastern direction was not only a waste of potential, the vastness and wilderness - it was also inherently "unmaritime" and thus devoid of all the positive qualities associated with maritime cultures (to remind: willpower, enterprise, open-mindedness, hunger for knowledge, patriotism). It epitomized the risk for the Polish culture becoming land culture and losing the chance of acquiring those qualities and through them - political and economic strength. Yet another aspect of the argument was a warning that embracing the continental dimension of the Polish character - that associated with the Jagiellon tradition and the southeastern direction - could lend support to German revisionist arguments and thus weaken the Polish stand on the Baltic Sea shore. Among those arguments were namely ones stating that Poland was not a maritime country and therefore did not need access to the sea nor its own ports, as it could just as well be served by ports of the other countries - for example Germany.

The south-eastern direction leading towards the Black Sea occupied, therefore, an ambivalent place on the Polish maritime mental maps in the interwar period. On the one hand, it epitomized the risk of wasting the nation's energy and falling into the same trap that had brought Poland's downfall in the past. On the other - it formed a part of the Intermarium ideology and vision of foreign policy, a way of connecting Poland and Polish trade with the Black and Aegean Seas and becoming the regional leader, a counterweight to Germany and the USSR. The two ideas - of maritime Poland and of the Intermarium - overlapped in certain discourses: the one

\footnotetext{
27 Kwiatkowski, 2.

28 Bujak, 19.
} 
of Poland's security and defense against the stronger neighbors or the one of Poland acquiring the status of a regional power. They did not, however, form parts of the same discourse; the federalistic idea of Intermarium, despite referring to the sea in its name, was in its ideological dimension land based. Those who were the most fervent in addressing the nation and its leaders with exhortations for an active maritime policy and formation of a maritime outlook, and who spoke about the sea as "the country's lungs and indispensable organ of its free existence", looked to the north, not to the south-east. Maritime Poland they envisaged was supposed to be Poland on the Baltic Sea (although with trade connections in different directions), not Poland from one sea to the other.

\section{Conclusions}

This paper has aimed to analyze the interwar Poland's visions of the country's place in reference to the Baltic and the Black Seas. As has been shown, these visions included elements of both nationalistic, nation-building and empire-building discourses. They concentrated on the Polish nation's historical and predicted or postulated future development - this development was considered in relation both to the seas and to the country's neighbors. Whether by playing an active and important role in the Baltic Sea region or by the creation of the region of Intermarium reaching to the Black and Adriatic Seas, the aim was to become a regional power strong enough to withstand the pressure from Germany and the Soviet Union. However, the relations to both seas differed: only the one to which the country had direct access, the Baltic, became the object of an active and emotional propaganda of the sea and projects of creating national maritime consciousness.

\section{References:}

Dopierała, Bogusław. Wokół polityki morskiej Drugiej Rzeczypospolitej. Studia historyczne. Poznań: Wydawnictwo Poznańskie, 1978.

'Editorial Policy.' Baltic and Scandinavian Countries. A survey of peoples and states on the Baltic with special regard to their history, geography and economics 4 (1938). 
Hackmann, Jörg. 'Zugang zum Meer: Die Ostsee in der polnischen Historiografie.' Nordeuropaforum 2 (2004): 43-66. Accessed at http:/ /edoc.hu-berlin.de/nordeuropaforum/2004-2/hackmann-joerg-43/XML/ on 5.04.2013.

Hobsbawm, Eric. 'Introduction: Inventing Traditions.' In The Invention of Tradition. Ed. Eric Hobsbawm, Terence Ranger. Cambridge: Cambridge University Press, 1983, 1-14.

Kirkien, Leszek. Między Wistą a ujściem Dunaju. Problem battycko-czarnomorski. Warszawa: Instytut Wschodni, 1932.

Kołodziejczyk, Arkadiusz. 'Liga Morska i Kolonialna.' In Encyklopedia Historii Drugiej Rzeczypospolitej. Warszawa: Wiedza Powszechna, 1999, 191.

Kwiatkowski, Eugeniusz. 'Powrót Polski nad Bałtyk.' In Obrona Pomorza. Ed. Józef Borowik. Torun: Wydawnictwa Instytutu Bałtyckiego, 1930, 120.

Lehti, Marko. A Baltic League as a Construct of the New Europe. Frankfurt am Main, New York: Peter Lang, 1999.

Leitgeber, Bolesław. 'The Dardanelles and the Sound.' Baltic and Scandinavian Countries. A survey of peoples and states on the Baltic with special regard to their history, geography and economics 3 (1937): 71-76.

Łossowski, Piotr. Polska w Europie i na świecie 1918-1939. Szkice z dziejów polityki zagranicznej i położenia międzynarodowego II Rzeczypospolitej. Warszawa: Książka i Wiedza, 1990.

Małowist, Marian. 'The Baltic and the Black Sea in Medieval trade.' Baltic and Scandinavian Countries. A survey of peoples and states on the Baltic with special regard to their history, geography and economics 3 (1937): 3642.

Piotrowski, Bernard. W stużbie nauki i narodu. Instytut Battycki w latach 19251939. Poznań: Wydawnictwo Naukowe UAM, 1991.

Sobieski, Wacław. Walka o Pomorze. Poznań: Nakład Księgarni św. Wojciecha, 1928.

Srokowski, Stanisław. Instytut Bałtycki i jego zadania. 1926.

Światopogląd morski. Ed. Józef Borowik. Toruń: Wydawnictwa Instytutu Bałtyckiego, 1934.

Troebst, Stefan. "'Intermarium" and "Wedding to the Sea": Politics of History and Mental Mapping in East Central Europe.' European Review of History 10 (2003): 293-321. 
Znamierowska-Rakk, Elżbieta. 'Sprawa połączenia Bałtyku z Morzem Czarnym i Morzem Egejskim w polityce II Rzeczypospolitej.' In Międzymorze. Polska i kraje Europy Środkowo-Wschodniej XIX-XX wiek. Studia ofiarowane Piotrowi Łossowskiemu w siedemdziesiąta rocznice urodzin. Ed. Andrzej Ajnenkiel et al. Warszawa: Instytut Historii PAN, 1995, 287-298. 